\title{
Neuropeptide S receptor (version 2019.4) in the IUPHAR/BPS Guide to Pharmacology Database
}

\author{
Girolamo Caló ${ }^{1}$, Olivier Civelli ${ }^{2}$, Rainer K. Reinscheid and Chiara Ruzza ${ }^{1}$
}

1. University of Ferrara, Italy

2. University of California at Irvine, USA

\begin{abstract}
The neuropeptide S receptor (NPS, provisional nomenclature [18]) responds to the 20 amino-acid peptide neuropeptide $S$ derived from a precursor (NPS, POCOP6).
\end{abstract}

\section{Contents}

This is a citation summary for Neuropeptide $S$ receptor in the Guide to Pharmacology database (GtoPdb). It exists purely as an adjunct to the database to facilitate the recognition of citations to and from the database by citation analyzers. Readers will almost certainly want to visit the relevant sections of the database which are given here under database links.

GtoPdb is an expert-driven guide to pharmacological targets and the substances that act on them. GtoPdb is a reference work which is most usefully represented as an on-line database. As in any publication this work should be appropriately cited, and the papers it cites should also be recognized. This document provides a citation for the relevant parts of the database, and also provides a reference list for the research cited by those parts.

Please note that the database version for the citations given in GtoPdb are to the most recent preceding version in which the family or its subfamilies and targets were substantially changed. The links below are to the current version. If you need to consult the cited version, rather than the most recent version, please contact the GtoPdb curators.

\section{Database links}

Neuropeptide S receptor

http://www.guidetopharmacology.org/GRAC/FamilyDisplayForward?familyld=44

Introduction to Neuropeptide $S$ receptor

http://www.guidetopharmacology.org/GRAC/FamilyIntroductionForward?familyld=44

Receptors

NPS receptor

http://www.guidetopharmacology.org/GRAC/ObjectDisplayForward?objectld=302

\section{References}

1. Acevedo N, Sääf A, Söderhäll C, Melén E, Mandelin J, Pietras CO, Ezer S, Karisola P, Vendelin J and 
Gennäs GB et al.. (2013) Interaction between retinoid acid receptor-related orphan receptor alpha (RORA) and neuropeptide S receptor 1 (NPSR1) in asthma. PLoS ONE 8: e60111 [PMID:23565190]

2. Adori C, Barde S, Bogdanovic N, Uhlén M, Reinscheid RR, Kovacs GG and Hökfelt T. (2015) Neuropeptide S- and Neuropeptide S receptor-expressing neuron populations in the human pons. Front Neuroanat 9: 126 [PMID:26441556]

3. Beiderbeck DI, Lukas M and Neumann ID. (2014) Anti-aggressive effects of neuropeptide S independent of anxiolysis in male rats. Front Behav Neurosci8: 185 [PMID:24910598]

4. Bernier V, Stocco R, Bogusky MJ, Joyce JG, Parachoniak C, Grenier K, Arget M, Mathieu MC, O'Neill GP and Slipetz D et al.. (2006) Structure-function relationships in the neuropeptide $S$ receptor: molecular consequences of the asthma-associated mutation N107I. J. Biol. Chem. 281: 24704-12 [PMID:16790440]

5. Beste C, Konrad C, Uhlmann C, Arolt V, Zwanzger P and Domschke K. (2013) Neuropeptide S receptor (NPSR1) gene variation modulates response inhibition and error monitoring. Neuroimage 71: 1-9 [PMID:23319044]

6. Camarda V, Rizzi A, Ruzza C, Zucchini S, Marzola G, Marzola E, Guerrini R, Salvadori S, Reinscheid RK and Regoli $D$ et al.. (2009) In vitro and in vivo pharmacological characterization of the neuropeptide $S$ receptor antagonist [D-Cys(tBu)5]neuropeptide S. J. Pharmacol. Exp. Ther. 328: 549-55 [PMID:18971372]

7. Cannella N, Economidou D, Kallupi M, Stopponi S, Heilig M, Massi M and Ciccocioppo R. (2009) Persistent increase of alcohol-seeking evoked by neuropeptide $\mathrm{S}$ : an effect mediated by the hypothalamic hypocretin system. Neuropsychopharmacology 34: 2125-34 [PMID:19322167]

8. Castro AA, Moretti M, Casagrande TS, Martinello C, Petronilho F, Steckert AV, Guerrini R, Calo' G, Dal Pizzol F and Quevedo J et al.. (2009) Neuropeptide S produces hyperlocomotion and prevents oxidative stress damage in the mouse brain: a comparative study with amphetamine and diazepam. Pharmacol. Biochem. Behav. 91: 636-42 [PMID:19022279]

9. Clark SD, Duangdao DM, Schulz S, Zhang L, Liu X, Xu YL and Reinscheid RK. (2011) Anatomical characterization of the neuropeptide $S$ system in the mouse brain by in situ hybridization and immunohistochemistry. J. Comp. Neurol. 519: 1867-93 [PMID:21452235]

10. D'Amato M, Bruce S, Bresso F, Zucchelli M, Ezer S, Pulkkinen V, Lindgren C, Astegiano M, Rizzetto M and Gionchetti $P$ et al.. (2007) Neuropeptide s receptor 1 gene polymorphism is associated with susceptibility to inflammatory bowel disease. Gastroenterology 133: 808-17 [PMID:17854592]

11. Dine J, lonescu IA, Avrabos C, Yen YC, Holsboer F, Landgraf R, Schmidt U and Eder M. (2015) Intranasally applied neuropeptide $S$ shifts a high-anxiety electrophysiological endophenotype in the ventral hippocampus towards a "normal"-anxiety one. PLoS ONE 10: e0120272 [PMID:25830625]

12. Domschke K, Reif A, Weber H, Richter J, Hohoff C, Ohrmann P, Pedersen A, Bauer J, Suslow T and Kugel $\mathrm{H}$ et al.. (2011) Neuropeptide $\mathrm{S}$ receptor gene -- converging evidence for a role in panic disorder. Mol. Psychiatry 16: 938-48 [PMID:20603625]

13. Donner J, Haapakoski R, Ezer S, Melén E, Pirkola S, Gratacòs M, Zucchelli M, Anedda F, Johansson LE and Söderhäll C et al.. (2010) Assessment of the neuropeptide S system in anxiety disorders.Biol. Psychiatry 68: 474-83 [PMID:20705147]

14. Duangdao DM, Clark SD, Okamura N and Reinscheid RK. (2009) Behavioral phenotyping of neuropeptide S receptor knockout mice. Behav. Brain Res. 205: 1-9 [PMID:19646487]

15. Erdmann F, Kügler S, Blaesse P, Lange MD, Skryabin BV, Pape HC and Jüngling K. (2015) Neuronal expression of the human neuropeptide S receptor NPSR1 identifies NPS-induced calcium signaling pathways. PLoS ONE 10: e0117319 [PMID:25714705]

16. Fedeli A, Braconi S, Economidou D, Cannella N, Kallupi M, Guerrini R, Calò G, Cifani C, Massi M and Ciccocioppo R. (2009) The paraventricular nucleus of the hypothalamus is a neuroanatomical substrate for the inhibition of palatable food intake by neuropeptide S. Eur. J. Neurosci. 30: 1594-602 [PMID:19821837]

17. Fendt M, Buchi M, Bürki H, Imobersteg S, Ricoux B, Suply T and Sailer AW. (2011) Neuropeptide S receptor deficiency modulates spontaneous locomotor activity and the acoustic startle response. Behav. Brain Res. 217: 1-9 [PMID:20888368]

18. Foord SM, Bonner TI, Neubig RR, Rosser EM, Pin JP, Davenport AP, Spedding M and Harmar AJ. (2005) 
International Union of Pharmacology. XLVI. G protein-coupled receptor list. Pharmacol. Rev. 57: 279-88 [PMID:15914470]

19. Gardella E, Romei C, Cavallero A, Trapella C, Fedele E and Raiteri L. (2013) Neuropeptide S inhibits release of 5-HT and glycine in mouse amygdala and frontal/prefrontal cortex through activation of the neuropeptide S receptor. Neurochem. Int. 62: 360-6 [PMID:23411412]

20. Ghazal P, Corsi M, Roth A, Faggioni F, Corti C, Merlo Pick E, Pucciarelli S, Ciccocioppo R and Ubaldi M. (2014) Paradoxical response to the sedative effects of diazepam and alcohol in C57BL/6J mice lacking the neuropeptide S receptor. Peptides 61: 107-13 [PMID:25240770]

21. Gottlieb DJ, O'Connor GT and Wilk JB. (2007) Genome-wide association of sleep and circadian phenotypes. BMC Med. Genet. 8 Suppl 1: S9 [PMID:17903308]

22. Guerrini R, Camarda V, Trapella C, Caló G, Rizzi A, Ruzza C, Fiorini S, Marzola E, Reinscheid RK and Regoli D et al.. (2009) Further studies at neuropeptide s position 5: discovery of novel neuropeptide $S$ receptor antagonists. J. Med. Chem. 52: 4068-71 [PMID:19473027]

23. Guerrini R, Salvadori S, Rizzi A, Regoli D and Calo' G. (2010) Neurobiology, pharmacology, and medicinal chemistry of neuropeptide S and its receptor. Med Res Rev30: 751-77 [PMID:19824051]

24. Gupte J, Cutler G, Chen JL and Tian H. (2004) Elucidation of signaling properties of vasopressin receptorrelated receptor 1 by using the chimeric receptor approach. Proc. Natl. Acad. Sci. U.S.A. 101: 1508-1513 [PMID:14757815]

25. Han RW, Chang M, Peng YL, Qiao LY, Yin XQ, Li W and Wang R. (2009) Central Neuropeptide S inhibits distal colonic transit through activation of central Neuropeptide $S$ receptor in mice. Peptides 30: 1313-7 [PMID:19540430]

26. Han RW, Xu HJ, Zhang RS, Wang P, Chang M, Peng YL, Deng KY and Wang R. (2014) Neuropeptide S interacts with the basolateral amygdala noradrenergic system in facilitating object recognition memory consolidation. Neurobiol Learn Mem 107: 32-6 [PMID:24211255]

27. Han RW, Yin XQ, Chang M, Peng YL, Li W and Wang R. (2009) Neuropeptide S facilitates spatial memory and mitigates spatial memory impairment induced by $\mathrm{N}$-methyl-D-aspartate receptor antagonist in mice. Neurosci. Lett. 455: 74-7 [PMID:19429110]

28. Han RW, Zhang RS, Xu HJ, Chang M, Peng YL and Wang R. (2013) Neuropeptide S enhances memory and mitigates memory impairment induced by MK801, scopolamine or $A \beta_{1-42}$ in mice novel object and object location recognition tasks. Neuropharmacology 70: 261-7 [PMID:23454528]

29. Holanda AD, Asth L, Santos AR, Guerrini R, de P Soares-Rachetti V, Calo' G, André E and Gavioli EC. (2015) Central adenosine $A 1$ and $A 2 A$ receptors mediate the antinociceptive effects of neuropeptide $S$ in the mouse formalin test. Life Sci. 120: 8-12 [PMID:25447449]

30. Ionescu IA, Dine J, Yen YC, Buell DR, Herrmann L, Holsboer F, Eder M, Landgraf R and Schmidt U. (2012) Intranasally administered neuropeptide S (NPS) exerts anxiolytic effects following internalization into NPS receptor-expressing neurons. Neuropsychopharmacology 37: 1323-37 [PMID:22278093]

31. Jüngling K, Seidenbecher T, Sosulina L, Lesting J, Sangha S, Clark SD, Okamura N, Duangdao DM, Xu YL and Reinscheid RK et al.. (2008) Neuropeptide S-mediated control of fear expression and extinction: role of intercalated GABAergic neurons in the amygdala. Neuron 59: 298-310 [PMID:18667157]

32. Kallupi M, Cannella N, Economidou D, Ubaldi M, Ruggeri B, Weiss F, Massi M, Marugan J, Heilig M and Bonnavion $\mathrm{P}$ et al.. (2010) Neuropeptide $\mathrm{S}$ facilitates cue-induced relapse to cocaine seeking through activation of the hypothalamic hypocretin system. Proc. Natl. Acad. Sci. U.S.A. 107: 19567-72 [PMID:20974945]

33. Kumsta R, Chen FS, Pape HC and Heinrichs M. (2013) Neuropeptide $S$ receptor gene is associated with cortisol responses to social stress in humans. Biol Psychol 93: 304-7 [PMID:23466585]

34. Kushikata T, Yoshida H, Kudo M, Salvadori S, Calo G and Hirota K. (2011) The effects of neuropeptide S on general anesthesia in rats. Anesth. Analg. 112: 845-9 [PMID:21288975]

35. Laas K, Eensoo D, Paaver M, Lesch KP, Reif A and Harro J. (2015) Further evidence for the association of the NPSR1 gene A/T polymorphism (Asn107lle) with impulsivity and hyperactivity. J. Psychopharmacol. (Oxford) 29: 878-83 [PMID:25744621] 
36. Laas K, Reif A, Kiive E, Domschke K, Lesch KP, Veidebaum T and Harro J. (2014) A functional NPSR1 gene variant and environment shape personality and impulsive action: a longitudinal study. J. Psychopharmacol. (Oxford) 28: 227-36 [PMID:23325374]

37. Laitinen T, Polvi A, Rydman P, Vendelin J, Pulkkinen V, Salmikangas P, Mäkelä S, Rehn M, Pirskanen A and Rautanen A et al.. (2004) Characterization of a common susceptibility locus for asthma-related traits. Science 304: 300-4 [PMID:15073379]

38. Lennertz L, Franke PE, Grabe HJ, Rampacher F, Schulze-Rauschenbach S, Guttenthaler V, Ruhrmann S, Pukrop R, Klosterkötter J and Falkai P et al.. (2013) The functional coding variant Asn107lle of the neuropeptide $S$ receptor gene (NPSR1) influences age at onset of obsessive-compulsive disorder. Int. J. Neuropsychopharmacol. 16: 1951-8 [PMID:23680103]

39. Lennertz L, Quednow BB, Schuhmacher A, Petrovsky N, Frommann I, Schulze-Rauschenbach S, Landsberg MW, Steinbrecher A, Höfels S and Pukrop R et al.. (2012) The functional coding variant Asn107lle of the neuropeptide $S$ receptor gene (NPSR1) is associated with schizophrenia and modulates verbal memory and the acoustic startle response. Int. J. Neuropsychopharmacol. 15: 1205-15 [PMID:22078257]

40. Leonard SK, Dwyer JM, Sukoff Rizzo SJ, Platt B, Logue SF, Neal SJ, Malberg JE, Beyer CE, Schechter LE and Rosenzweig-Lipson S et al.. (2008) Pharmacology of neuropeptide S in mice: therapeutic relevance to anxiety disorders. Psychopharmacology (Berl.) 197: 601-11 [PMID:18311561]

41. Leonard SK and Ring RH. (2011) Immunohistochemical localization of the neuropeptide S receptor in the rat central nervous system. Neuroscience 172: 153-63 [PMID:20950671]

42. Li W, Chang M, Peng YL, Gao YH, Zhang JN, Han RW and Wang R. (2009) Neuropeptide S produces antinociceptive effects at the supraspinal level in mice. Regul. Pept. 156: 90-5 [PMID:19345242]

43. Liao Y, Lu B, Ma Q, Wu G, Lai X, Zang J, Shi Y, Liu D, Han F and Zhou N. (2016) Human Neuropeptide S Receptor Is Activated via a Goq Protein-biased Signaling Cascade by a Human Neuropeptide S Analog Lacking the C-terminal 10 Residues. J. Biol. Chem. 291: 7505-16 [PMID:26865629]

44. Liu X, Zeng J, Zhou A, Theodorsson E, Fahrenkrug J and Reinscheid RK. (2011) Molecular fingerprint of neuropeptide S-producing neurons in the mouse brain. J. Comp. Neurol. 519: 1847-66 [PMID:21452230]

45. Lukas $M$ and Neumann ID. (2012) Nasal application of neuropeptide $S$ reduces anxiety and prolongs memory in rats: social versus non-social effects. Neuropharmacology 62: 398-405 [PMID:21871467]

46. Medina G, Ji G, Grégoire S and Neugebauer V. (2014) Nasal application of neuropeptide S inhibits arthritis pain-related behaviors through an action in the amygdala. Mol Pain 10: 32 [PMID:24884567]

47. Meis S, Bergado-Acosta JR, Yanagawa Y, Obata K, Stork O and Munsch T. (2008) Identification of a neuropeptide $S$ responsive circuitry shaping amygdala activity via the endopiriform nucleus. PLOS ONE 3 : e2695 [PMID:18628994]

48. Melamed JY, Zartman AE, Kett NR, Gotter AL, Uebele VN, Reiss DR, Condra CL, Fandozzi C, Lubbers LS and Rowe BA et al.. (2010) Synthesis and evaluation of a new series of Neuropeptide S receptor antagonists. Bioorg. Med. Chem. Lett. 20: 4700-3 [PMID:20510609]

49. Okamura N, Garau C, Duangdao DM, Clark SD, Jüngling K, Pape HC and Reinscheid RK. (2011) Neuropeptide $S$ enhances memory during the consolidation phase and interacts with noradrenergic systems in the brain. Neuropsychopharmacology 36: 744-52 [PMID:21150909]

50. Okamura N, Habay SA, Zeng J, Chamberlin AR and Reinscheid RK. (2008) Synthesis and pharmacological in vitro and in vivo profile of 3-oxo-1,1-diphenyl-tetrahydro-oxazolo[3,4-a]pyrazine-7carboxylic acid 4-fluoro-benzylamide (SHA 68), a selective antagonist of the neuropeptide S receptor. J. Pharmacol. Exp. Ther. 325: 893-901 [PMID:18337476]

51. Okamura N, Hashimoto K, lyo M, Shimizu E, Dempfle A, Friedel S and Reinscheid RK. (2007) Genderspecific association of a functional coding polymorphism in the Neuropeptide $S$ receptor gene with panic disorder but not with schizophrenia or attention-deficit/hyperactivity disorder. Prog. Neuropsychopharmacol. Biol. Psychiatry 31: 1444-8 [PMID:17669576]

52. Okazaki Y, Furuno M, Kasukawa T, Adachi J, Bono H, Kondo S, Nikaido I, Osato N, Saito R and Suzuki H et al.. (2002) Analysis of the mouse transcriptome based on functional annotation of 60,770 full-length 
CDNAs. Nature 420: 563-73 [PMID:12466851]

53. Pañeda C, Huitron-Resendiz S, Frago LM, Chowen JA, Picetti R, de Lecea L and Roberts AJ. (2009)

Neuropeptide $S$ reinstates cocaine-seeking behavior and increases locomotor activity through corticotropin-releasing factor receptor 1 in mice. J. Neurosci. 29: 4155-61 [PMID:19339610]

54. Peng YL, Han RW, Chang M, Zhang L, Zhang RS, Li W, Han YF and Wang R. (2010) Central Neuropeptide $S$ inhibits food intake in mice through activation of Neuropeptide $S$ receptor. Peptides 31: 2259-63 [PMID:20800637]

55. Peng YL, Zhang JN, Chang M, Li W, Han RW and Wang R. (2010) Effects of central neuropeptide S in the mouse formalin test. Peptides 31: 1878-83 [PMID:20603169]

56. Pulga A, Ruzza C, Rizzi A, Guerrini R and Calo G. (2012) Anxiolytic- and panicolytic-like effects of Neuropeptide $S$ in the mouse elevated T-maze. Eur. J. Neurosci. 36: 3531-7 [PMID:22928868]

57. Pulkkinen V, Ezer S, Sundman L, Hagström J, Remes S, Söderhäll C, Greco D, Dario G, Haglund C and Kere $\mathrm{J}$ et al.. (2014) Neuropeptide $S$ receptor 1 (NPSR1) activates cancer-related pathways and is widely expressed in neuroendocrine tumors. Virchows Arch. 465: 173-83 [PMID:24915894]

58. Pulkkinen V, Majuri ML, Wang G, Holopainen $P$, Obase $Y$, Vendelin J, Wolff $H$, Rytilä $P$, Laitinen LA and Haahtela T et al.. (2006) Neuropeptide $S$ and G protein-coupled receptor 154 modulate macrophage immune responses. Hum. Mol. Genet. 15: 1667-79 [PMID:16600990]

59. Raczka KA, Gartmann N, Mechias ML, Reif A, Büchel C, Deckert J and Kalisch R. (2010) A neuropeptide $S$ receptor variant associated with overinterpretation of fear reactions: a potential neurogenetic basis for catastrophizing. Mol. Psychiatry 15: 1045, 1067-74 [PMID:20628342]

60. Raiteri L, Luccini E, Romei C, Salvadori S and Calò G. (2009) Neuropeptide S selectively inhibits the release of 5-HT and noradrenaline from mouse frontal cortex nerve endings. Br. J. Pharmacol. 157: 474-81 [PMID:19371348]

61. Reinscheid RK. (2007) Phylogenetic appearance of neuropeptide S precursor proteins in tetrapods. Peptides 28: 830-7 [PMID:17293003]

62. Reinscheid RK, Xu YL, Okamura N, Zeng J, Chung S, Pai R, Wang Z and Civelli O. (2005) Pharmacological characterization of human and murine neuropeptide s receptor variants. J. Pharmacol. Exp. Ther. 315: 1338-45 [PMID:16144971]

63. Ren W, Kiritoshi T, Grégoire S, Ji G, Guerrini R, Calo G and Neugebauer V. (2013) Neuropeptide S: a novel regulator of pain-related amygdala plasticity and behaviors. J. Neurophysiol. 110: 1765-81 [PMID:23883857]

64. Rizzi A, Vergura R, Marzola G, Ruzza C, Guerrini R, Salvadori S, Regoli D and Calo G. (2008) Neuropeptide $S$ is a stimulatory anxiolytic agent: a behavioural study in mice. Br. J. Pharmacol. 154: 471-9 [PMID:18376418]

65. Ruland T, Domschke K, Schütte V, Zavorotnyy M, Kugel H, Notzon S, Vennewald N, Ohrmann P, Arolt V and Pfleiderer B et al.. (2015) Neuropeptide $S$ receptor gene variation modulates anterior cingulate cortex Glx levels during CCK-4 induced panic. Eur Neuropsychopharmacol 25: 1677-82 [PMID:26235955]

66. Ruzza C, Asth L, Guerrini R, Trapella C and Gavioli EC. (2015) Neuropeptide S reduces mouse aggressiveness in the resident/intruder test through selective activation of the neuropeptide $S$ receptor. Neuropharmacology 97: 1-6 [PMID:25979487]

67. Ruzza C, Pulga A, Rizzi A, Marzola G, Guerrini R and Calo' G. (2012) Behavioural phenotypic characterization of CD-1 mice lacking the neuropeptide S receptor. Neuropharmacology 62: 1999-2009 [PMID:22248636]

68. Ruzza C, Rizzi A, Camarda V, Pulga A, Marzola G, Filaferro M, Novi C, Ruggieri V, Marzola E and Vitale G et al.. (2012) [tBu-D-Gly5]NPS, a pure and potent antagonist of the neuropeptide $S$ receptor: in vitro and in vivo studies. Peptides 34: 404-11 [PMID:22342393]

69. Ruzza C, Rizzi A, Malfacini D, Pulga A, Pacifico S, Salvadori S, Trapella C, Reinscheid RK, Calo G and Guerrini R. (2015) In vitro and in vivo pharmacological characterization of a neuropeptide $S$ tetrabranched derivative. Pharmacol Res Perspect 3: e00108 [PMID:25692025]

70. Ruzza C, Rizzi A, Trapella C, Pela' M, Camarda V, Ruggieri V, Filaferro M, Cifani C, Reinscheid RK and 
Vitale G et al.. (2010) Further studies on the pharmacological profile of the neuropeptide S receptor antagonist SHA 68. Peptides 31: 915-25 [PMID:20172007]

71. Sartori SB, Maurer V, Murphy C, Schmuckermair C, Muigg P, Neumann ID, Whittle N and Singewald N. (2016) Combined Neuropeptide S and D-Cycloserine Augmentation Prevents the Return of Fear in Extinction-Impaired Rodents: Advantage of Dual versus Single Drug Approaches. Int. J. Neuropsychopharmacol. 19: [PMID:26625894]

72. Sato and Suli et al.. (2002) Novel G protein-coupled receptor protein and DNA thereof. Patent number: WO0231145.

73. Scherer SW, Cheung J, MacDonald JR, Osborne LR, Nakabayashi K, Herbrick JA, Carson AR, ParkerKatiraee L, Skaug J and Khaja R et al.. (2003) Human chromosome 7: DNA sequence and biology. Science 300: 767-72 [PMID:12690205]

74. Shao YF, Wang C, Xie JF, Kong XP, Xin L, Dong CY, Li J, Ren WT and Hou YP. (2016) Neuropeptide S ameliorates olfactory spatial memory impairment induced by scopolamine and MK801 through activation of cognate receptor-expressing neurons in the subiculum complex. Brain Struct Funct 221: 3327-36 [PMID:26323488]

75. Shao YF, Zhao P, Dong CY, Li J, Kong XP, Wang HL, Dai LR and Hou YP. (2013) Neuropeptide S facilitates mice olfactory function through activation of cognate receptor-expressing neurons in the olfactory cortex. PLoS ONE 8: e62089 [PMID:23614017]

76. Smith KL, Patterson M, Dhillo WS, Patel SR, Semjonous NM, Gardiner JV, Ghatei MA and Bloom SR. (2006) Neuropeptide $S$ stimulates the hypothalamo-pituitary-adrenal axis and inhibits food intake.

Endocrinology 147: 3510-8 [PMID:16574794]

77. Spada J, Sander C, Burkhardt R, Häntzsch M, Mergl R, Scholz M, Hegerl U and Hensch T. (2014) Genetic association of objective sleep phenotypes with a functional polymorphism in the neuropeptide $\mathrm{S}$ receptor gene. PLoS ONE 9: e98789 [PMID:24896296]

78. Tancredi T, Guerrini R, Marzola E, Trapella C, Calo G, Regoli D, Reinscheid RK, Camarda V, Salvadori S and Temussi PA. (2007) Conformation-activity relationship of neuropeptide $S$ and some structural mutants: helicity affects their interaction with the receptor. J. Med. Chem. 50: 4501-8 [PMID:17696420]

79. Thorsell A, Tapocik JD, Liu K, Zook M, Bell L, Flanigan M, Patnaik S, Marugan J, Damadzic R and Dehdashti SJ et al.. (2013) A novel brain penetrant NPS receptor antagonist, NCGC00185684, blocks alcohol-induced ERK-phosphorylation in the central amygdala and decreases operant alcohol selfadministration in rats. J. Neurosci. 33: 10132-42 [PMID:23761908]

80. Trotter BW, Nanda KK, Manley PJ, Uebele VN, Condra CL, Gotter AL, Menzel K, Henault M, Stocco R and Renger JJ et al.. (2010) Tricyclic imidazole antagonists of the Neuropeptide S Receptor.Bioorg. Med. Chem. Lett. 20: 4704-8 [PMID:20615693]

81. Vendelin J, Pulkkinen V, Rehn M, Pirskanen A, Räisänen-Sokolowski A, Laitinen A, Laitinen LA, Kere J and Laitinen T. (2005) Characterization of GPRA, a novel G protein-coupled receptor related to asthma. Am. J. Respir. Cell Mol. Biol. 33: 262-70 [PMID:15947423]

82. Vitale G, Filaferro M, Ruggieri V, Pennella S, Frigeri C, Rizzi A, Guerrini R and Calò G. (2008) Anxiolyticlike effect of neuropeptide $S$ in the rat defensive burying. Peptides 29: 2286-91 [PMID:18793688]

83. Wan Saudi WS, Halim MA, Rudholm-Feldreich T, Gillberg L, Rosenqvist E, Tengholm A, Sundbom M, Karlbom U, Näslund E and Webb DL et al.. (2015) Neuropeptide S inhibits gastrointestinal motility and increases mucosal permeability through nitric oxide. Am. J. Physiol. Gastrointest. Liver Physiol. 309: G62534 [PMID:26206857]

84. Xu YL, Gall CM, Jackson VR, Civelli O and Reinscheid RK. (2007) Distribution of neuropeptide S receptor mRNA and neurochemical characteristics of neuropeptide S-expressing neurons in the rat brain. J. Comp. Neurol. 500: 84-102 [PMID:17099900]

85. Xu YL, Reinscheid RK, Huitron-Resendiz S, Clark SD, Wang Z, Lin SH, Brucher FA, Zeng J, Ly NK and Henriksen SJ et al.. (2004) Neuropeptide S: a neuropeptide promoting arousal and anxiolytic-like effects. Neuron 43: 487-97 [PMID:15312648]

86. Zhang S, Jin X, You Z, Wang S, Lim G, Yang J, McCabe M, Li N, Marota J and Chen let al.. (2014) 
Persistent nociception induces anxiety-like behavior in rodents: role of endogenous neuropeptide S. Pain 155: 1504-15 [PMID:24793908]

87. Zhang Y, Gilmour BP, Navarro HA and Runyon SP. (2008) Identifying structural features on 1,1-diphenylhexahydro-oxazolo[3,4-a]pyrazin-3-ones critical for Neuropeptide $S$ antagonist activity. Bioorg. Med.

Chem. Lett. 18: $4064-7$ [PMID:18555684]

88. Zhu H, Mingler MK, McBride ML, Murphy AJ, Valenzuela DM, Yancopoulos GD, Williams MT, Vorhees CV and Rothenberg ME. (2010) Abnormal response to stress and impaired NPS-induced hyperlocomotion, anxiolytic effect and corticosterone increase in mice lacking NPSR1. Psychoneuroendocrinology 35: 111932 [PMID:20171785] 